\title{
INTRODLCTION
}

ANDREW KAHN AND IRINA REYFMAN

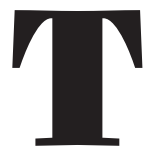

he Journey from St. Petersburg to Moscow is the work that made Alexander Radishchev an underground celebrity. 1790, this work of travel literature and political critique is one of the most notorious books of the eighteenth century. Banned until nearly the end of the Imperial period, it was read in manuscript copies that circulated clandestinely (there are about seventy extant copies dating from 1790, many with readers' comments), in the few rare copies of the first edition that survived (Alexander Pushkin acquired such a copy), or finally, in copies published by the émigré press outside Russia starting in 1856 . Radishchev's arrest, on June 30,1790 , came at the start of the third decade of a reign that began in 1762, when Catherine II took the throne. Because her clash with this dedicated civil servant and gifted freethinker came toward the end of the epoch, it overshadowed her long record of accomplishment. Radishchev's sentence of exile looked like an act of despotic intolerance, casting doubt on Catherine's commitment to the improvement of social welfare and other progressive tenets of the Enlightenment. Russian historians have continued to debate whether the principles of toleration, reform, and 
rational government that Catherine had made cornerstones of her reputation were real or mere virtue signaling. The historical irony is that Radishchev's intellectual qualities and philosophical views were very much the product of the values of toleration, Westernization, and reform that Catherine had championed for much of her reign.

\section{THE MAN AND HIS WORK}

Born in Moscow in 1749, Radishchev was the scion of a wealthy and well-educated provincial nobleman, a descendant of a Tatar prince who entered Russian service under Ivan the Terrible. The future writer spent the first years of his life on one of his father's numerous estates and was taught at home; beginning in 1756 or 1757 , he lodged in the Moscow house of a relative on his mother's side, Mikhail Argamakov, the director of Moscow University, to be taught together with his children. ${ }^{1}$ Their education was first-rate: Moscow University professors gave them private lessons, they had access to the university library, and they were able to attend public lectures at the university. In 1762, the young Radishchev entered state service as a page to the newly enthroned Empress. He spent the first year in Moscow, where the court had relocated for Catherine's coronation, and then moved with the court to St. Petersburg. His education continued at the Corps of Pages, where he studied physics, mathematics, geography, and languages. He also learned music, dance, and fencing. The duties of a page required Radishchev to appear at court, and his first attempt at creative composition, the synopsis of a one-act comedy in French cowritten with his classmate P. I. Chelishchev (the Ch. of the chapter "Chudovo"), was staged at the court theater. ${ }^{2}$ 
In 1766, Radishchev was one of a select group of twelve young noblemen sent to Leipzig University to further their education. Each of them was given room and board and a bursary of eight hundred rubles, a substantial sum. The young people studied natural philosophy, law, logic, geography, physics, and mathematics; they also learned languages-German, French, and Latin. Among their instructors were first-rate European scholars and scientists, including the philosopher Ernst Platner and poet Christian Gellert. Radishchev also studied medicine. The connections he makes in his major writings between forms of sensibility and sensation may have been rooted in his education at Leipzig University. The Age of Reason was also an Age of Sensibility, and the human propensity for sympathy and empathy was seen as a matter of hardwiring in the body as much as a product of a refined education (discussions of pedagogy in this period in Russia, as well as in Western Europe, considered these parallel influences). The foundation for Radishchev's knowledge of a wide range of Enlightenment ideas about the body and soul, as well as about political economy and the law, was laid during his Leipzig years.

The period of study at Leipzig was formative not only educationally but also politically and emotionally. Radishchev developed firm friendships with some of his fellow students, most especially Fyodor Ushakov (1748/49-1770), whom he would later commemorate in an important biography, The Life of Fyodor Ushakov (1789). The biography recounts how Russian students, with Ushakov as their ringleader, rebelled against their corrupt supervisor to protest poor living conditions. This experience was seminal for Radishchev, who later traced his mature thinking about political action and legitimate forms of protest back to this event. The Life of Fyodor Ushakov also 
describes the titular character's death from venereal disease, stressing his courage in the face of death and connecting his firm behavior with his leadership qualities. Radishchev is unusually frank about Ushakov's libido and the sexually transmitted disease that prematurely killed him. The topic of prostitution and syphilis recurs in episodes of the Journey that consider passions, including sexual passions, as an important factor in human behavior. ${ }^{3}$ The friendship with Ushakov was thus a turning point for Radishchev, providing both a political and an emotional education.

On his return to Russia, Radishchev and two others of his cohort, including his friend Alexei Kutuzov, the future Freemason and eventual dedicatee of the Journey, served briefly in the Senate before entering military service. Radishchev served as a military lawyer until his retirement in 1775. Soon after retirement, Radishchev married Anna Vasilyevna Rubanovskaya (who died prematurely in 1783). He resumed his service career in January 1778 as a civil servant in the Commerce College, with the rank of collegiate assessor. He held this post under Alexander Vorontsov, the well-educated, progressive nobleman, diplomat, and brother of Catherine's confidante Ekaterina Dashkova. At the time, Vorontsov was president of the Commercial College and had recruited Radishchev to work for the Commission on Commerce. He remained a loyal patron to Radishchev during his career and, especially, after his arrest and exile in 1790.

A civil servant of distinction and ability who had a practical grasp of policy implementation (he visited the port cities on the Baltic to see things with his own eyes), Radishchev seems never to have put a foot wrong. When the government passed gubernatorial reforms in 1780, Radishchev was seconded to State Councillor Dal, the director of St. Petersburg Customs, and assumed oversight for trade entering 
the port at St. Petersburg. In this capacity he was said to have commanded the respect of his colleagues for his incorruptibility, a conspicuous virtue when contrasted with the venality of officialdom much illustrated in the Journey. He made steady progress up the ranks, achieving several promotions in the early 1780 . In 1789 he was designated director of St. Petersburg Customs.

Arrested a month after the publication of the Journey, Radishchev was imprisoned in the notorious Peter and Paul Fortress, investigated, and condemned to death in late July. In early September, Catherine commuted the death sentence, replacing it with exile to Siberia. On September 8, 1790, in chains and under guard, Radishchev began his journey to Ilimsk, a small fortress not far from the Angara River. Thanks to Vorontsov, the chains were soon removed, and on his way to Siberia Radishchev spent significant time in Moscow, Nizhny Novgorod, Tobolsk, and Irkutsk, which eased his journey. His sister-in-law, Ekaterina Rubanovskaya, and his two younger children joined him in Tobolsk. Rubanovskaya became Radishchev's common-law wife (marriages between in-laws were prohibited), with whom he had three children. She died on the family's way back to European Russia in 1797.

Radishchev arrived in Ilimsk in January 1792 and left in February 1797, having been granted permission to live in Nemtsovo, one of his estates, by the new ruler, Paul. After Paul was assassinated in March 1801, Alexander I fully pardoned the writer and offered him a position on the Legislative Commission to work on the codification of Russian law. Steeped in Western legal theory and knowledgeable about Russian legal practice, Radishchev joined the commission's work with enthusiasm. Several of his pieces on jurisprudence date from his year and a half with the commission. In September 1802, 
however, he committed suicide by drinking nitrohydrochloric acid. His motivation remains a mystery. It has been conjectured that he may have taken his life either because he feared another period of Siberian exile, as his son Pavel suggests in his biography of his father, or out of his general disillusionment with the constitutional project in which he was involved at the time. It is significant, however, that he had been thinking and writing about suicide ever since Fyodor Ushakov voiced his desire to kill himself instead of dying a slow and painful death during his illness in Leipzig.

From early on, Radishchev found in writing a medium to explore his thoughts about personal and public matters of concern. During his time in Leipzig and for several years after his return to Russia, he was chiefly engaged in translations from French and German; most important among these was Abbé de Mably's Observations sur les Grecs, which was published anonymously in 1773. Around the same time, Radishchev turned to literature. In 1779-82 he worked on the metrically innovative "oratory" "Creation of the World"; he included it in the early version of the Journey, where it followed the excerpts from the iambic ode "Liberty," written around 1783. In its full form, the ode discusses the social contract and the right it gives the sovereign people to protest against a corrupt monarch. Radishchev's examples of champions of liberty include Cromwell against the Crown and, for the American colonies, Washington's revolt against the British Empire.

While in the Peter and Paul Fortress, Radishchev began writing a work that perhaps provides some insights into his authorial motives for the Journey. It is based on the Life of St. Philaret the Merciful, who lived in the first century AD in Asia Minor. A prosperous and charitable man, Philaret lost his estate to robbers and became a pauper. 
Nonetheless, he continued his charitable work, and God eventually rewarded him. Radishchev uses this Life as a canvas for his own biography, to communicate with his family and to explain his actions. It is significant that he chose the Life of the saint who, like the author of the Journey, was sensitive to the sufferings of humanity.

Most of Radishchev's works of literature (excluding the Journey) were made available to the reading public when his sons Nikolai and Pavel published an edition in six volumes (1806-11). Literary activities were clearly just as important to him as his political interests. His diverse writings included a work of natural philosophy on the nature of the soul and the body, A Historical Song about the idea of historical change, a long poem, Bova, based on folk traditions (inspired as well by Voltaire's burlesque epic The Maid of Orleans), and another long poem, Songs Sung at the Competition in Honor of the Ancient Slavic Divinities, written in tribute to the Russian medieval epic the Lay of Igor's Campaign. Yet Radishchev was not much appreciated as a writer by the generation that followed. His openness to experimentation and the use of highly idiosyncratic forms stymied most readers. There were some exceptions. Pushkin, for instance, admired both Radishchev's experiments with meters and his poetry. His 1836 essay "Alexander Radishchev" is often cited for its criticism of Radishchev's "barbaric" style, but Pushkin also paid tribute to Radishchev's "honesty of intention" in the Journey and this work's comprehensive summation of "all French philosophy of the period." Radishchev's persecution and the initial hostility to his ideas were instrumental in shaping how readers interpreted the work's political goals in the last century of Imperial Russia, as well as in Soviet Russia, where virtually from the 1917 revolution Radishchev was lionized as a proto-Bolshevik. 


\section{THE JOURNEY: ITS PUBLICATION}

\section{AND RECEPTION}

Textual studies of the composition of Radishchev's Journey-his second longest work after the complex quasi-materialist treatise he wrote in exile on the body-soul duality - suggest that he began writing when Catherine's policies were more permissive and she still had a reputation as a reformer. The first part of the Journey written was "An Oration About Lomonosov." The other chapters followed, and by the end of 1788 the version that Radishchev submitted to the censor was complete. The censor approved this short version for publication. Censorship, both state and church, in the Catherine period was unsystematic and sporadically applied; in general, the 178 os were a period of flourishing for small presses and of growth for university presses.

V.A. Zapadov calculated that Radishchev added about 40 percent more material after the book was approved by the censor. ${ }^{4}$ Many of the added passages were the ones that particularly enraged Catherine. Had Radishchev deliberately sought early permission in order to evade censorship? That seems unlikely for at least two reasons: first, because it assumes that the censor would have been vigilant, whereas the evidence suggests that he may not have read the shorter version with any attention; second, and more important, there is no basis on which to claim that Radishchev expected his work would be received as an outrage or as a "personal attack" on the monarch. His superior and old friend Vorontsov regarded the book as no more than an "incautious blunder," while Catherine saw it as an attempt to foment, as stated in the official charge of July 1790, "disobedience and social discord."5 Everything suggests, in fact, that the Empress's 
fury and her personal involvement in Radishchev's arrest took him and others by surprise.

Radishchev published the Journey anonymously and at his own expense in May 1790, using his own hand press, obtained the previous year. At 650 copies, the number he confessed in the transcript of his interrogation, the print run was large, especially as Radishchev undoubtedly knew that, at the time, few books sold more than 300 copies. He must have hoped his work would attract wide interest among the educated elite. He clearly expected to recover some of the costs via sales through the bookshop of G. K. Zotov. Some copies were sold, and Radishchev sent several to his friends and acquaintances, including Vorontsov's sister, Catherine's longtime friend and ally, Princess Dashkova; and the great poet and senator G. R. Derzhavin, who also fell under suspicion and distanced himself from Radishchev by writing a poem in which he condemned him as "a Russian Mirabeau." The rest Radishchev destroyed when he learned that the authorities were looking for the book's author. Catherine acquired her own copy-which survived with her marginal notes harshly condemning many of the book's ideas and denouncing the author as a dangerous rebel.

By June 1790, Catherine had determined to her own satisfaction Radishchev's authorship (her initial suspicions that he had an accomplice coauthor were rejected) and that he was, in her words, "a rebel even worse than Pugachev." His arrest followed an investigation directed by Count Alexander Bezborodko, one of Catherine's most valued statesmen and a man of cultivated sensibility, who argued for leniency. On the one hand, he believed that Radishchev had not violated the letter of the law, since free presses were permitted by a decree of 1783; on the other hand, the immediate context of 
the French Revolution was impossible to ignore, as were passages in Radishchev's book urging the establishment of equality and praising the regicide Cromwell. It was no help to Radishchev that the rumor mill about French spies in St. Petersburg had gone into overdrive, including allegations about a suspected plot to assassinate the Empress attributed to the Masonic Martinists, with whom the work's dedicatee Andrei Kutuzov had links. ${ }^{8}$ Evidence that the book was a succès de scandale in demand by readers (the documented investigation speaks of "the great curiosity of the public for the book"); that perhaps as many as fifty copies had gone unaccounted for; and that a translation into German was already in preparation (untrue, as it happened) exacerbated tensions. Radishchev was imprisoned in the Peter and Paul Fortress, his interrogation conducted by S. I. Sheshkovsky, who, as the dreaded head of the Secret Chancery, was nicknamed "knout-flogger." In mid-July Radishchev addressed to Sheshkovsky a letter of extenuation and apology intended for the ruler. The questions put to Radishchev were in effect scripted by Catherine; they asked Radishchev to explain whether he felt "the significance of his crime" and to gloss the meaning of passages regarded as explicitly of criminal intentionality. ${ }^{9}$ The official charge spoke of a "personal affront" to the Empress and a "determination to stir up the people against their masters." The death sentence decreed on July 24 th was confirmed by the Senate in early September, after Radishchev had been stripped of his rank (legislation forbade the execution of nobles). Catherine commuted the sentence to ten years of Siberian exile. This second decree noted the exceptional gesture of "clemency" (miloserdie), one of the Enlightenment values that differentiated the Enlightened autocrat from the tyrant, in sparing Radishchev, who was then sent east under armed convoy. 
In 1811, when Radishchev's sons published their edition of his works, they omitted the Journey because of the ongoing censorship ban. For most of the nineteenth century, the Journey remained a clandestine book, notwithstanding the anonymous publication of a sporadic chapter or two in journals in Russia and Germany and mentions in works of reference such as Bantysh-Kamensky's Dictionary of Memorable People (1836). After the political turmoil of 1825 , Radishchev's name was taboo for a decade, and precious few readers had access to his writings. Among them was Alexander Pushkin, who may have read Radishchev's book in manuscript even before purchasing a rare copy in 1835 (only sixty-seven copies of Radishchev's printing have been accounted for). One indicator of Pushkin's engagement with Radishchev's book can be found in the title of his essay "Journey from Moscow to Petersburg" (1833-35, unfinished). The piece examines the chapters of Radishchev's Journey in reverse order, providing a set of revisionist commentaries for which Radishchev's text is always the departure point. It was a sign of the times that in 1837 the minister of education, Count S. S. Uvarov, excluded Pushkin's article "Alexander Radishchev" from the third volume of his literary journal The Contemporary, extending the ban to the posthumous edition of his works. The ban remained in force until Pavel Annenkov's important edition of Pushkin's works in 1857, when the novelist Ivan Goncharov, no less, was the censor.

In 1858, Nikolai Ogarev and Alexander Herzen, exiles based in London and often dubbed the fathers of Russian socialism, published in effect the second edition of Radishchev's Journey in The Bell (Kolokol) of 1858, their famous radical journal. Although full of errors and unauthorized editorial interventions, this notable edition (reprinted with its distortions in Leipzig in 1876) stimulated Pavel 
Radishchev in 1859 or 1860 to apply to Tsar Alexander II for permission to publish this and other works by his father. He had published in 1858 his own memoir of his father, partly drawing on rare materials, including a manuscript copy of the Journey provided by the historian Mikhail Pogodin. Pavel succeeded against enormous resistance in publishing his memoir (the censor, reputed to be a secret friend to radicals, lost his job over the matter). However, his efforts to publish the Journey met with refusal in 1860 and again in 1865 , during which time he sent Herzen a copy of Radishchev's massive ode "Liberty" for publication. The ban on the Journey was lifted by the Tsar in March 1868. Rumors of new editions proliferated, and a memoir by Radishchev's other son, Nikolai, was allowed to appear, while some mentions of Radishchev as the author of the Journey in reference works were tolerated (a fuller version of memoirs by both sons would be banned until 1912). An 1872 edition of the Journey was advertised, but it never appeared, and the print run was destroyed in 1873. Radishchev's most important work remained taboo in nineteenth-century Russia, and signs of a thaw were scarce. The continued suppression of this work only enhanced its reputation among budding radicals in post-Emancipation Russia.

\section{THE JOURNEY AS A NEW FORM OF POLITICAL LITERATURE}

In his introduction to the first and only translation of Radishchev's Journey into English, Roderick Page Thaler articulated a view long held in the West and in Soviet criticism of Radishchev as one of "the earliest of the liberal Russian intelligentsia" whose main purpose in 
writing the book was to condemn serfdom and convince Russian landowners to abolish it before the serfs revolted. ${ }^{10}$ Indeed, Radishchev was one of the first-if not the first-proponents of individual rights in Russia, a position based on his extensive reading of natural law theorists who argued for the equality of all in the state of nature (although some also contended that separate national histories proved that the class structures that emerged were natural for those societies). Radishchev opposed serfdom-even though he never attempted to free his own serfs. He advocated greater humanity in the management of estates, but his stance also looks defensive of an autocracy that put itself at risk by failing to undertake some reform. Recruiting Radishchev to the ranks of the "liberal intelligentsia" speaks very much of a Cold War outlook. Radishchev wrote toward the end of a reign that had in many respects been progressive in legislating reforms of Russia's political economy and, in certain peripheral areas, experimenting with the emancipation of state serfs. Catherine the Great was one of the intellectual stars of the European Enlightenment, a celebrity correspondent of many great thinkers such as Voltaire and D'Alembert, as well as host to Diderot in 1774 in St. Petersburg. Given the fear caused by the French Revolution, 1790 was a bad time to agitate for further reforms to Russia's highly topdown power structure, in which the monarch ruled almost at the grace of the wealthiest nobles, whose fortunes in turn were vested in the land. The Journey contains two "projects for the future," and while they have a utopian quality, they are also rooted in present circumstance and hint at the possibility that Catherine might reform the Table of Ranks, the hierarchical system Peter had created for staffing the imperial bureaucracy, and create financial incentives for the better treatment of serfs by the landed gentry. 
A purely political reading of Radishchev's rich, complex, multifaceted, and profoundly innovative book would be reductive, however. For all the evidentiary value Radishchev's Journey has for historians, it is of course not a straightforward piece of documentation or social analysis. There is much more in his Journey than an exposition of his political beliefs, condemnation of serfdom, and criticism of the contemporary Russian monarchy. Most important, it is not a political treatise but a work of literature whose genre is unique. Despite the heated arguments about Radishchev's political intentions that have persisted since its first publication, the Journey remains not fully appreciated as a work that uses its multiple types of discourse and polyphonic style of narration to offer perspectives on questions about Russian civilization at the end of Catherine's reign, when the European Enlightenment had come under assault from the French Revolution. The different perspectives of the literary characters from across the social spectrum, including serf and conscript narrators as well as landowners and high-ranking civil servants, emerge in how they tell their stories. There are also narrators who offer perspectives from outside the system by imagining a better future in the language of the allegorical dream and by offering utopian visions of progress.

Radishchev structured his work in twenty-five chapters, each of which is named for a post station where the traveler stops to rest and change horses. The chapters are preceded by a dedication whose addressee is Radishchev's boyhood friend Alexei Mikhailovich Kutuzov. The dedication addresses two of the most important human capacities: to engage in close observation of the world around one and to feel compassion by virtue of empathy. The former makes the latter possible. Wherever the traveler goes, he must be ready to keep his eyes open and actually see and not turn away 
from injustice but feel the pain it inflicts. By averting his gaze, man overlooks suffering and condones its existence. Outward observation is not the only mode of viewing, however, because the book also contains allegorical visions and dreams. They enlighten the traveler and allow him to see the failings, his own and mankind's, that lead to cruelty toward fellow humans.

While sometimes read as a work of political satire and brutal realism, the Journey's picture of Russia is anything but straightforwardly realistic (any more than Gogol's Dead Souls is simply a mirror held up to economic reality). Radishchev's debt to other writerswhether Vasily Trediakovsky for linguistic experimentation, the French anticolonial writer Abbé Raynal for models of slave rebellion stories, or Rousseau for his focus on one's own heart as a touchstone of virtue-makes it a highly literary work. Although Radishchev read pioneering writers of the social sciences, such as Condorcet and Adam Smith, and drew lessons on political economy and social justice from them, reading Radishchev is not like reading Adam Smith - certainly not the Adam Smith of The Wealth of Nations. For one thing, while Radishchev was expert at administrative memoranda, here his primary rhetorical mode is the story.

Radishchev understood the human self as an empirical being. While he does not deny that goodness may be an innate propensity, he believes that individual values are conditioned by a range of social, scientific, economic, and intellectual forces, and his use of a literary form aims to see how characters respond to competing interests. Travel literature was among the eighteenth century's most flexible literary modes, and it proved the optimal form for an inquiry into the state of Russian life-mostly rural life, but also life in the capitals - at that time. Episodes provide an opportunity 
to perform, in virtuous and sympathetic acts, the principles that the narrator holds to be universal. The Journey contains many stories intended to arouse emotional responses from readers, mainly indignation at injustice. Displays of philanthropy, fellow feeling, and sympathy provide essential narrative moments for demonstrating how sensibility is meant to work. But Radishchev's manner is not to let readers, or participants, indulge their feelings simply as an emotional reflex without considering the cause of their indignation. Sentimental fiction of the period encouraged readers to weep openly, because the shedding of tears was a display of feeling and affirmation of sensibility that required cultivation. For the historian Lynn Hunt, the seeds of revolution in France lay in the gradual development of sensibility brought on by literary movements. ${ }^{11}$ For Radishchev, the facile demonstration of virtue was insufficient, and the difficult manner he devised for the Journey may strive to promote reading of a particularly thoughtful kind. One role of Radishchev's narrator is to bring home the social component in roused feeling by framing it in the conceptual vocabulary of sensibility, social contract, and the law. Does this reflect a mistrust of the efficacy of fiction? Radishchev most likely did not share the view, widespread in the eighteenth century (and enshrined in Russia by the neoclassical theorist Alexander Sumarokov in his "Epistle on Poetry," 1748), that fiction corrupted. His Sternean moments of digression and plotting are not a facile imitation of the sentimental style. They show a commitment to the underlying belief that narration can re-create empirical reality and affect sensibility especially strongly when written in a style that is antisentimentalist or at the very least not Karamzinian or Sternean.

Journey narratives require some form of itinerary and movement in time and space as an axis of development. The form is highly 
flexible, permitting embedded stories, anecdotes related second- or even thirdhand, and multiple forms of place description, such as historical excursus or a highly aesthetic type of picturesque. Stories in Radishchev's Journey do not extend beyond the book's basic unit of the chapter. Yet over the course of the book, a set of case studies develops in the demonstration of moral principles advocated by the narrator and other storytellers. Like the picaresque, the travel narrative depends on the staging of random encounters and stories told or overheard before the voyager can continue. For instance, in the chapter "Spasskaya Polest," when the narrator parts with the victim of a shipwreck whose extended tale has been reproduced in the previous chapter, "Chudovo," he overhears the conversation of an official and his wife concerning a corrupt boss and his taste for oysters. Listening is just as important as observing; the narrator must remain attuned to the stories he hears from others, anecdotes that expand the range of topics treated. In the same chapter, after the narrator meets an unfortunate passenger who is being ruined in the law courts, he responds to his interlocutor's distress physiologically, which results in an allegorical dream that affords an interior vision. Sometimes, as it happens, the narrator need not go anywhere to become a witness to tales about miscarriages of justice.

For Radishchev, forms of discourse and forms of discovery go together. In travel literature, we frequently see that tenets held to be universal face challenges in local practices and customs, forcing the narrator to raise questions about beliefs, their origins, and their validity. Performativity is one important technique in the way the work lays bare the epistemological foundations of certain ideas. In the chapter "Bronnitsy," the narrator has a religious experience we could call a revelation. One effect of the scientific revolution that 
preceded the Enlightenment-in which no discoveries were more important than Newton's theories of light-was to generate religious controversy, questioning whether revelation afforded a privileged verification of the divine in the workings of man or whether the only basis for explanation of natural effects was empirical and scientific. Reconciling science or natural philosophy and Christian dogma occupied much of the intellectual energy of the period, and Radishchev was well informed on the range of heterodox views, from deism to materialist atheism, that faced Christian theology (topics he treated later in his treatise On Man, His Mortality, and Immortality). In "Bronnitsy," the traveler arrives at a place that had once been the location of a pagan cult in the pre-Slavic period and where now a small church stands. His travel in this instance becomes imaginary as he envisions himself "transported to antiquity." The purpose of his time travel and indulgence in an imagined act of divination is to learn the future. In his emotional stupor, the traveler enters a state similar to that of the initiate into Masonic mysteries. He hears a divine voice reproaching him for trying to pierce the "impenetrable shield of unknowability" and explaining that limits in human knowledge are a form of self-protection designed by a divinity to preserve man in a state of blissful ignorance. Thunder, the sign of the pagan god Perun, peals and seemingly confirms the truth of this conclusion. However, it impels the traveler to meditate further on the nature of names for the divine, from the Eastern and classical gods to the Christian God, and to end with an evocation of "O my God!" The traveler's declaration of his monotheistic faith is nondenominational and based on an inner belief that spells the difference, he states, between the believer and the atheist. The institutions of religions, their practices and their buildings, are transient and therefore an insufficient basis for belief 
in the divine. Ultimately, the traveler concludes, as did Plato and Rousseau, that religion is a personal matter based on an individual aptitude to hear "a secret voice." That affirmation, however, is not the last word. The chapter ends with a quotation adapted from Joseph Addison's Cato that presents a vision of cosmic destruction in which "something" will persist even beyond the extinction of the stars and the cooling of the sun. What Radishchev means exactly is a matter for speculation, but he does not call this energy "God" and seems to associate it with Nature. In mentioning "the crush of worlds," Addison's lines seem to side with an idea fashionable in the eighteenth century, starting with the French philosopher Fontenelle (whose treatise On the Plurality of Worlds was translated into Russian in 1728 by the highly European and pro-Petrine prince Antiokh Kantemir) that there is a multiplicity of worlds. This concept was long seen as a challenge to Christian dogma. How could one reconcile the idea of multiple worlds with the account of Genesis? Did it mean that there were multiple gods? In this chapter, Radishchev acknowledges that historically there have been many names for a supernatural power but finds that since empirical proof for the existence of God cannot be produced definitively, it is one's own spiritualism that convinces best. This short chapter turns out to be a demonstration of the anthropology of religion and a typical example of Radishchev's method in making plots out of philosophical inquiry.

Traditional readings of Radishchev's book have seen it largely as a damning satire, a critique of serfdom and the serf economy, and there is no denying the force with which it exposes all sorts of social ills and evils that arise from abuses of power. These range from corporal punishment and the corruption of the judicial system to sexual exploitation and bribe taking. Far from blaming Catherine for all 
these ills, Radishchev focuses attention on the newly ennobledsmall landowners who advanced up the social ladder through service to the state in the reigns of monarchs from Peter to Catherine II. But Radishchev's fall from grace was arguably more a story of aspirations disappointed than tyranny opposed: he was not an advocate of revolution and preferred reform, even hoping that Catherine would take to heart his advice on renovating Russian laws to address human exploitation, economic and often sexual. For all his use of sad stories to illustrate the types of exploitation brought about by fundamental inequalities of class, economic situation, and gender, Radishchev keeps alive a more positive undercurrent. In two chapters bearing the subtitle "Project for the Future," he imagines the promise of a virtuous monarch and state. Radishchev employs here one of his favorite words, a term that is hard to translate: blazhenstvo. Meaning "bliss," "prosperity," "the common good," and "felicity" and distinct from "good fortune" (schastie), it comes up time and again as a reminder that the human condition has the potential for much happiness when social conditions are reasonable. Late in life, Radishchev became a reader of Condorcet, a great advocate of the rationalist reform of society, whose belief in gender equality and the progress of the human spirit he seems to have shared. The optimism of his century may have been one reason for a critique of Russia born of aspirations for improvement. In 1790, after serving under a monarch who had enshrined social reforms in several important legislative packages, Radishchev hoped for more, and the Journey can be read as his attempt to synthesize in one complex literary work a lifetime spent in various forms of study_ of natural and comparative law, the laws of the Russian Empire, and systems of taxation, as well as natural philosophy, as science was called in the eighteenth century. 


\section{TRANSLATING THE JOURNEY}

Until the eighteenth century, the written form of the Russian language derived strongly from the ecclesiastical Church Slavonic. The rise of a secular literature accompanied the development of a new vernacular idiom marked by a more modern vocabulary, conversational tone, and varied patterns of syntax. While Radishchev can be an effective storyteller, he did not adopt for the Journey the newer style that had become the norm in Russia in the 1790s, famously crafted by the other great prose writer of the age, Nikolai Karamzin (1766-1826). On the contrary, for his Journey, Radishchev developed an artificially archaic and difficult style, not only using and overusing existing Church Slavonic forms but also creating his own "Slavonicized” expressions. This linguistic oddity has occasioned much comment and criticism, and even native Russians find the laborious syntax, neologisms, and pseudo-Slavonic register a challenge.

The only English translation of Radishchev's 1790 travelogue was published by Harvard University Press in 1958. Two translators worked on it: first Leo Wiener (1862-1939), who died before publishing his translation; and then Roderick Page Thaler, who edited Wiener's translation and supplied it with an introduction, notes, and index. As Thaler informs the reader in his preface, the Harvard historian Michael Karpovich served as his chief consultant during this work. Thaler labeled Radishchev a poor prose writer, seeing the style of his Journey as monotonous, repetitive, uneven, awkward, and often old-fashioned against Karamzin as a benchmark. Such a characterization indicates that Thaler (and, most probably, the original translator Leo Wiener as well) never suspected that Radishchev's idiosyncratic writing was a consciously created 
stylistic device, part of his design to make his travelogue effective as a literary work.

All readers of the Journey know that it is a difficult read. Anyone who has looked at other writings by Radishchev will have seen ample counterevidence that he was also entirely able to write clear prose. The question is why Radishchev devised a style designed to make the reader work hard at the meaning. Many passages in the Journey are not simply outdated (as Thaler believed) but artificially archaic, as has been demonstrated by a number of scholars who have examined Radishchev's linguistic choices. The fact that some chapters of Radishchev's book are written in a language that does not present any difficulties to the reader, while others are almost beyond comprehension - so difficult are their word choice, grammar, and syntax-indicates that Radishchev intentionally changed the degree of difficulty to influence his readers in a certain way. It is significant, for example, that the most linguistically obscure chapters and passages usually present the most provocative ideas. Finally, as has been pointed out by historians of the Russian literary language, Radishchev's reputation as a bad writer originates with Karamzin and his supporters, who used his archaized style as an example of incorrect linguistic choices in a quarrel that took place in the early nineteenth century with the cultural conservative Alexander Shishkov (17541841) and his followers.

Radishchev thus wrote in a Russian that was deliberately awkward. He is not, whatever anyone says about the literariness of the final product, a writer without a style or a theory of style. To be sure, norms of prose idiom in the period remained in flux, with translators and original writers still experimenting with German and Latin syntactic forms as well as other prosodic features. Yet Radishchev's 
purpose was not to experiment with style for its own sake. He wished to create a distinctive medium to convey his ideas and to manipulate the reader. One of the most curious and innovative chapters in the work is "Tver." It brings together, for a rare change, both prose and poetry and represents an extended critique of poetic forms in Russia, as illustrated by the many stanzas excerpted from Radishchev's much longer poem Liberty. It is almost needless to say that a poem with that title, while presented under the guise of a lesson in style, also has a political message, and stanzas cited for their rhetorical verve vividly denounce tyranny. Much of what has been said about Radishchev's prose holds true of his poetry. In the hope of preserving that sense of a form overloaded with drama and abstraction, we have translated the excerpts in verse, approximating the ten-line stanza and rhyme scheme. And while Radishchev's narrative mode can be fleet, the sometimes turgid style and strained idiom function as a tool for focusing the reader's mind on his sometimes abstract philosophical vocabulary and on the highly visual element of his prose, which relies on anecdote, episode, and verbal painting as a way of aligning emotional and intellectual content. Radishchev took his epigraph for the Journey from Trediakovsky's Tilemakhida. That work was a poetic resetting of an important didactic prose work by the French archbishop Fénelon, used as a textbook in the education of princes. In his foreword to Tilemakhida, Trediakovsky stressed the idea that poetic language not only has to differ from colloquial language but also has to correspond to the content of the work and, furthermore, to impart wisdom to the reader. By the late eighteenth century, the work's neoclassical style and Trediakovsky's highly artificial idiom struck readers as passé. The epigraph signaled that the Journey would combine narrative and didacticism in the manner of 
Fénelon's original educational treatise-cum-novel and that Radishchev, in spite of popular opinion, intended to emulate Trediakovsky in devising a work of linguistic and stylistic idiosyncrasy. ${ }^{12}$

Certain aspects of Radishchev's style cannot be reproduced in a translation. But can a translator completely disregard the stylistic complexion of the Journey and not try at least to indicate the strangeness of Radishchev's word choice, grammar, and syntax? A smooth Radishchev would be a contradiction in terms. But once syntactic effects specific to Radishchev are acknowledged as daringly disjointed in the original, and once it is accepted that only some of these are eligible to be transferred formally intact into English, stretching translation to be the faithful re-creation of all aspects would be self-defeating (the most notorious example of such translation perhaps being Vladimir Nabokov's Eugene Onegin). We recognize that the Journey's stylistic opacity is part of its meaning and have aimed to retain it where that can be done without undue stretching of the norms of English. At the same time, we have also aimed to use a more straightforward English syntax where understanding is little changed by ironing out syntactic knots in isolated phrases. The question is about the overall reading experience, and we trust that the effects of Radishchev's idiosyncratic style and voice, where they have been captured, will give a sufficient cumulative sense of what kind of writer he is.

The reader may find it helpful, then, to have an outline here of the problems posed and solutions offered. These can be discussed in terms of layout, syntax, and lexicon. Radishchev's paragraphing has been retained in this translation. The original printed punctuation of the Journey is very much that of an eighteenth-century work, sometimes with very long sentences broken up by commas alone or cast 
in a succession of verbal phrases choppily strung together. Following the example of Laurence Sterne, an important model in the writing of sensibility across Europe including Russia, Radishchev makes expressive use of the dash. He also uses the dash inconsistently to indicate dialogue and direct speech, and our practice has been to modernize and substitute quotation marks and also delineate voices where long dashes are originally missing.

Syntax is the most challenging feature for the reader and the translator. The complexities relate to the length and structure of subordinate clauses; the framing of scenes with near formulaic expressions to indicate arrivals and departures; and nonstandard word order. There are certainly meaningful instances in which chapters adopt a more formal tone and periodic syntax commensurate with serious topics. It is to be expected that Radishchev would formulate complex observations about the law, social justice, institutions, and other matters in complex ways, just as many of the writers of the period he read on these topics did. Some of the challenges posed by Radishchev's syntax are not unique to him and are familiar from much prose of the period. The page-long sentences to be found sometimes in the Journey are no more archaic than the majestic sentences typical of eighteenth-century English prose masters such as Samuel Johnson, Edward Gibbon, or David Hume. In English translation, preserving all of the far-ranging sentences that spool into the nesting of clauses would prove counterproductive. There are times when little of the sense has been lost, in our view, by dividing a page into a succession of shorter sentences or by shaping clauses made up of a string of phrases joined by commas with the more explicit divisions of semicolons, colons, and dashes to stave off syntactical implosion. We have generally preferred to normalize the Russian 
syntax to produce a readable English version. In some instances, the result is an English text that is actually more accessible than a knotty piece of Russian.

Length is not the only syntactic feature that is difficult to preserve. Radishchev's use of gerunds and participles in setting up narrative sequences looks overcomplicated by the standard of Karamzin and Pushkin. Typically, "having arrived," "having approached," "having driven up," characters then speak or act. This is a point of grammar that, arguably, conveys how consistently Radishchev emphasizes process-action and reaction-and his technique in setting up encounters and moving characters on and off is to underscore the beginnings and endings of speech acts. Similarly, Radishchev piles up clauses when creating coordinated actions, as in the following sentence, given here literally: "The having arrived detachment rescued this barbarian from the hands of peasants raging against him." Our translation turns gerundive and participial clauses into the more modern prepositional clauses that suit contemporary English, as seen in this example: "When it arrived, a detachment of soldiers rescued this barbarian from the hands of his angry peasants." Radishchev can also string together a series of separate subject-predicate combinations, punctuated only with commas. He condenses into a short space entire chain reactions of perception, feeling, and response. These are the moments that are meant to lead to moral realizations, in the reader if not always in the fictional characters. Our translation imitates his pattern, separating successive verbs only with commas.

The rules of word order in Russian, while not absolutely fixed, had acquired a more regular shape by the late eighteenth century. The freedom Radishchev exercises creates an unsettling impression and 
is undoubtedly one of his most effective devices for slowing down the reader. In these instances, the translator can decide on a case-bycase basis how much of the original wording can be conveyed-or, essentially, how much strain can be tolerated. In general, it is our assumption that when readers open a translation, they accept that there is a barrier of a kind between them and the original and wish for accuracy of meaning without constant stylistic reminders of how remote the original stands from the present idiom. This may be all the more so with a text removed in time by a couple of centuries. The matter is not simple, however, given our firm belief that form and content are inextricably linked in Radishchev's travelogue. For that reason, we have also sought, at least in some places, to retain an element of syntactic irregularity when the formal complication of the original underpins the message. The bookish language Radishchev uses, especially his insistence on nouns emphasizing process, focuses attention on the internal physical, moral, and psychological processes that define human action, reaction, and interaction in the Journey. The translator into English has some flexibility in choosing between noun forms based on a single root to express action-e.g., "attaining the shore" versus "the attainment of the shore." We have followed the English preference for nouns based on participles such as "attaining" but have tried to retain denominative nouns where the effect isn't grossly stilted, because Radishchev's point is to turn the mundane into some larger category (and vocabulary is a tool of defamiliarization). The clumsiness typical of this text should, however, feel like bumps in the road and not like obstacles, as Radishchev's narrative often hits its stride to achieve momentum and focus.

Ultimately, a modern translation cannot imitate closely Radishchev's style and remain readable; at the same time, the translator 
cannot disregard entirely the artificial idiom Radishchev created for the Journey. We have aimed to provide the readability of an accurate but accessible modern version while also making reasonable efforts to convey an impression of the stylistic dimension of a work of extraordinary historical importance.

\section{NOTES}

1. Biografiia A. N. Radishcheva, napisannaia ego synov'iami, ed. D. S. Babkin (Moscow: Izdatel'stvo Akademii nauk SSSR, 1959), 37.

2. Biografiia A. N. Radishcheva, 54 .

3. M. I. Sukhomlinov, A. N. Radishchev, avtor "Puteshestviia iz Peterburga v Moskvu" (St. Petersburg: Izdatel'stvo Imp. Akademii nauk, 1883), 6.

4. See V. A. Zapadov, 'Istoriia sozdaniia 'Puteshestviia iz Peterburga v Moskvu' i 'Vol'nosti," in A. N Radishchev, Puteshestvie is Peterburga v Moskvu. Vol'nost' (St. Petersburg: "Nauka," 1992), p. 518. Radishchev expanded "Spasskaya Polest," "Podberezye," "Novgorod," "Zaitsovo," "Edrovo," “Torzhok," and "Chornaya Gryaz.”; see Slovar' russkikh pisatelei XVIII veka, vol. 3 (St. Petersburg: "Nauka," 2010), p. 21.

5. Cited in Sukhomlinov, A. N. Radishchev, avtor, 54, and Biografia A. N. Radishcheva, 65.

6. Sukhomlinov, A. N. Radishchev, avtor, 31, 43. Honoré Gabriel Riqueti, comte de Mirabeau, was a French nobleman who supported the revolution but was later disgraced when he was found to be in the pay of France's enemies.

7. Biografiia A. N. Radishcheva, 64. Yemelyan Ivanovich Pugachev had led a peasant uprising earlier in Catherine's reign.

8. Sukhomlinov, A. N. Radishchev, avtor, 36 .

9. The life written by Pavel Radishchev, as published in the Biografia A. N. Radishcheva, amply draws on the documentary sources concerning Radishchev's case ("delo o Radishcheve").

10. In Aleksandr Nikolaevich Radishchev, A Journey from St. Petersburg to Moscow, trans. Leo Wiener, edited with an introduction and notes by Roderick Page Thaler (Cambridge, MA: Harvard University Press, 1958), vii. Leo Wiener (1862-1939) began teaching at Harvard in 1896 and eventually became the first American professor of Slavic literature. He was a prolific translator (including of the works of Tolstoy). As Thaler reports in the preface to the book, this "translation was first prepared by Professor Leo Wiener of Harvard University, who unhappily did not 
live to see it published" (vii). Thaler then reports that he "thoroughly revised" Wiener's translation and supplied the introduction and notes (viii). The Cold War position on Radishchev as a radical and early advocate of "liberal" values, meaning broadly republican or specifically democratic, was a view that took hold in scholarship of which David Marshall Lang, The First Russian Radical. Alexander Radishchev, 1749-1802 (London: Allen \& Unwin, 1959) is an example.

11. Lynn Hunt, The Family Romance of the French Revolution (Berkeley: University of California Press, 1992).

12. Radishchev's interest in Trediakovsky as a stylistic rule giver was genuine, informing his Monument to a Dactylic-Trochaic Knight (Pamiatnik daktilokhoreicheskomu vitiaziu, 1801). A formally heterogeneous work, part dialogue, part treatise, concerning aspects of versification and earlier influential writers such as Trediakovsky and Lomonosov, it can be read as an extension of the exploration of norms of Russian prosody versus prosody adapted from European models to which the chapter in the Journey "Tver" is dedicated. 
